Gazi University
Journal of Science
PART A: ENGINEERING AND INNOVATION
$\underline{\text { http://dergipark.org.tr/gujsa }}$

\title{
Chromitite Ore Types and Geochemical Investigation of Pozantı-Karsantı Ophiolite in Mazmılı Region (Turkey)
}

\author{
Ali TÜMÜKLÜiD \\ ${ }^{I}$ Nigde Omer Halisdemir University, Engineering Faculty, Geological Engineering Department, 51240, Nigde, Turkey
}

\begin{tabular}{ll}
\hline Keywords & Abstract \\
\hline Ophiolite & The Pozant1-Karsant1 Ophiolite located in the middle Taurus has significant chromitite reserves in \\
Chromitite & Turkey. The chromitite ore bodies belong to concordant and subconcordant form and are located \\
within mantle harzburgite surrounded by bodies of dunite. Chromitite ore types are small or medium \\
Geochemistry & $\begin{array}{l}\text { bodies of massive, disseminated, banded and nodular, also the result of a combination of at least two } \\
\text { of these types of ores consist of mixed-type ore. Chromite ores bear traces of plastic deformation under }\end{array}$ \\
Pozanti-Karsanti & the influence of lateral forces developing in the lateral direction. Plastic deformation is also observed \\
& at the micro scale. This study presents the concentrations of a complete suite of major $\left(\mathrm{SiO}_{2}, \mathrm{Cr} \mathrm{O}_{3}\right.$, \\
& $\mathrm{MgO}, \mathrm{Al}_{2} \mathrm{O}_{3}$, and $\left.\mathrm{FeO}(\mathrm{t})\right)$ and trace elements $(\mathrm{Ni}, \mathrm{Ti}, \mathrm{Co}, \mathrm{V}, \mathrm{Zn}, \mathrm{S}, \mathrm{Ca}, \mathrm{Ga}$ and $\mathrm{Cl})$ in podiform \\
chromitites of the Pozant1-Karsant Ophiolite. According to the chromite ore whole-rock geochemical \\
analysis, there was a positive relationship between the amount of $\mathrm{Cr}_{2} \mathrm{O}_{3}$ and $\mathrm{Zn}, \mathrm{V}, \mathrm{Ti}$, and $\mathrm{Co}$, while a \\
negative relationship was found between $\mathrm{Ni}, \mathrm{S}$ and Ca. This situation is opposite with the dunites in \\
which the chromite ore is located.
\end{tabular}

Cite

Tumuklu, A. (2021). Chromitite Ore Types and Geochemical Investigation of Pozant1-Karsanti Ophiolite in Mazmılı Region (Turkey). GU J Sci, Part A, 8(4), 537-550.

\begin{tabular}{lcc}
\hline Author ID (ORCID Number) & Article Process \\
\hline A. Tumuklu, 0000-0003-1215-8748 & Submission Date & 03.12 .2021 \\
& Revision Date & 15.12 .2021 \\
& Accepted Date & 29.12 .2021 \\
& Published Date & 30.12 .2021 \\
\hline
\end{tabular}

\section{INTRODUCTION}

The characteristics of the rock groups belonging to the ophiolites, the geochemical and mineralogicalpetrographical data obtained from the peridotites are important for the production of information about the upper mantle. Some studies on this subject; Niu et al., 1997; Takazawa et al., 2000; Choi et al., 2008; Dilek \& Morishita, 2009; Uysal et al., 2012. During the last decades, improvements in analytical techniques have allowed detailed geochemical studies of well-selected ophiolites and podiform chromitites on worldwide. One of the important topics for ore geology is ore type and major-trace element geochemistry. The only known economic mineral of the chromium element is the chromite mineral of spinel group and its ore chromitite. Therefore, the geochemistry and macro properties of the chromite ore are important in terms of $\mathrm{Cr}$ mining. In the current study, we present new ore chemistry of chromitite, mineralogy and macro-ore properties from Pozanti-Karsanti Ophiolite (PKO) (Southern-Turkey) in order to contribute to the understanding of podiform chromitite.

\section{GEOLOGICAL BACKGROUND AND DESCRIPTION OF THE POZANTI-KARSANTI OPHIOLITE}

Pozant1-Karsant1 Ophiolite forms the subject of this study is included Dilek \& Robinson (2003) group Tethyan-Carribbean Ophiolite and Bouider \& Nicolas (1985) harzbugite subtypes in Eastern Tauride belt in southern Turkey (Figure 1). In Southern Turkey, there are two main units, the ophiolitic and carbonate platform, within the Taurus belt. Overlying ophiolites are mid-late Cretaceous and carbonates are in the late 
Devonian to early Cretaceous age range (Blumenthal, 1946; Tekeli, 1981; Tekeli et al., 1984; Polat \& Casey, 1995). PKO is represent one of the largest fragments of oceanic in southern Turkey lies in the Eastern Tauride Belt (Aladağ region), offset from the Mersin ophiolite by the sinistral Ecemis fault (Çakır, 1978; Yetiş, 1984; Parlak et al., 2002). In upward succession, the rock groups belonging to the PKO are fragments of the neotethys ocean and consist of peridotites, mafic-ultramafic cumulates and gabbros belonging to tectonites. Cumulate gabbros and peridotites are cut by dolerite-diabase dykes (Figure 2) (An1l, 1990). Geochemical data of ultramafic and mafic groups of ophiolitic rocks show that this group is derived from tholeiitic material with island arc characteristic occurring in subduction zones (Parlak et al., 2002).

Chromitite ore production proceed continuously in about 50-60 area in PKO by open pit or underground mining methods since 1940. While raw material having high degree (35 and up \% Cr2O3) is evaluated without progress, low degree (min 5-7 and up \% $\mathrm{Cr} 2 \mathrm{O} 3$ ) ore is evaluated domestic and export markets mining stocks after concentrated in plant.

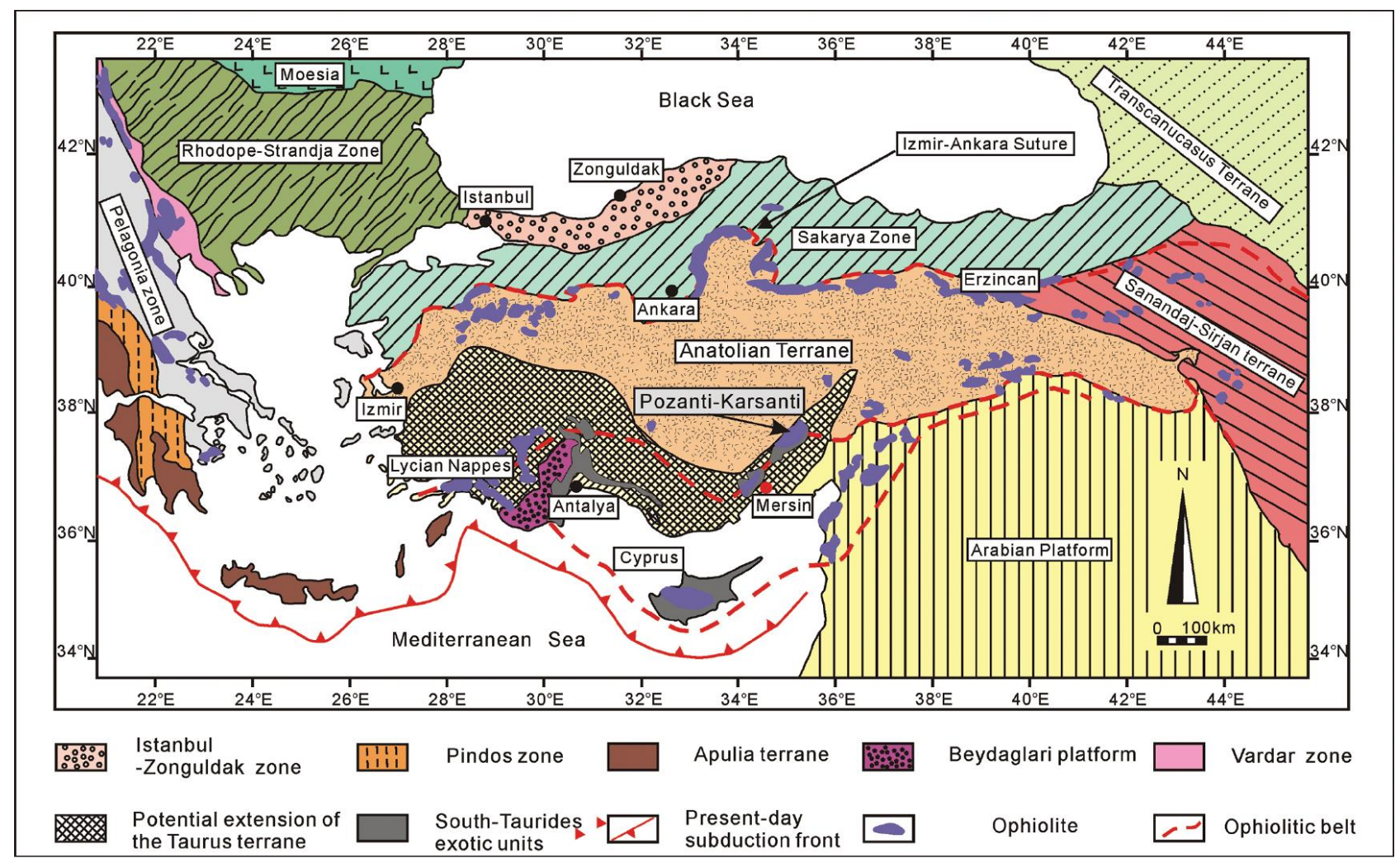

Figure 1. Distribution of Ophiolites and Surrounding Regions of Turkey (from Lian et al., 2017)

\section{SAMPLES AND ANALYTICAL METHODS}

Chromitite and peridotite samples used for this study are collected from the outcrop and mining area in the western part of the PKO in Mazmilı area. A total of 25 samples were collected from slickensides, ores and host rocks in chromitite outcrops and the mining areas in Mazmlı region. Thin sections were made from the rock samples and polished sections were made from the ore samples. Microscopic structures and textures and ore paragenesis were determined by examining the sections in N. Ömer Halisdemir University, Engineering Faculty, Geological Engineering Department, mineralogy-petrography laboratory. As a result of the microscope studies, 10 samples representing the mineralization were determined for geochemical analysis. The ore samples were grinded with a pulverizer at 80 mesh $(177 \mu)$ size in N. Ömer Halisdemir University Engineering Faculty Geological Engineering laboratories. The non-homogeneously grinded samples were homogenized using agate mortar and placed in 15 grams locked plastic bags and made ready for analysis. Geochemical analyses were carried out at TUBITAK-MAM Center with the wavelength dispersed X-Ray Fluorescence Spectrometer (WD-XRF) method, and the amounts of major oxides and trace elements were determined. 


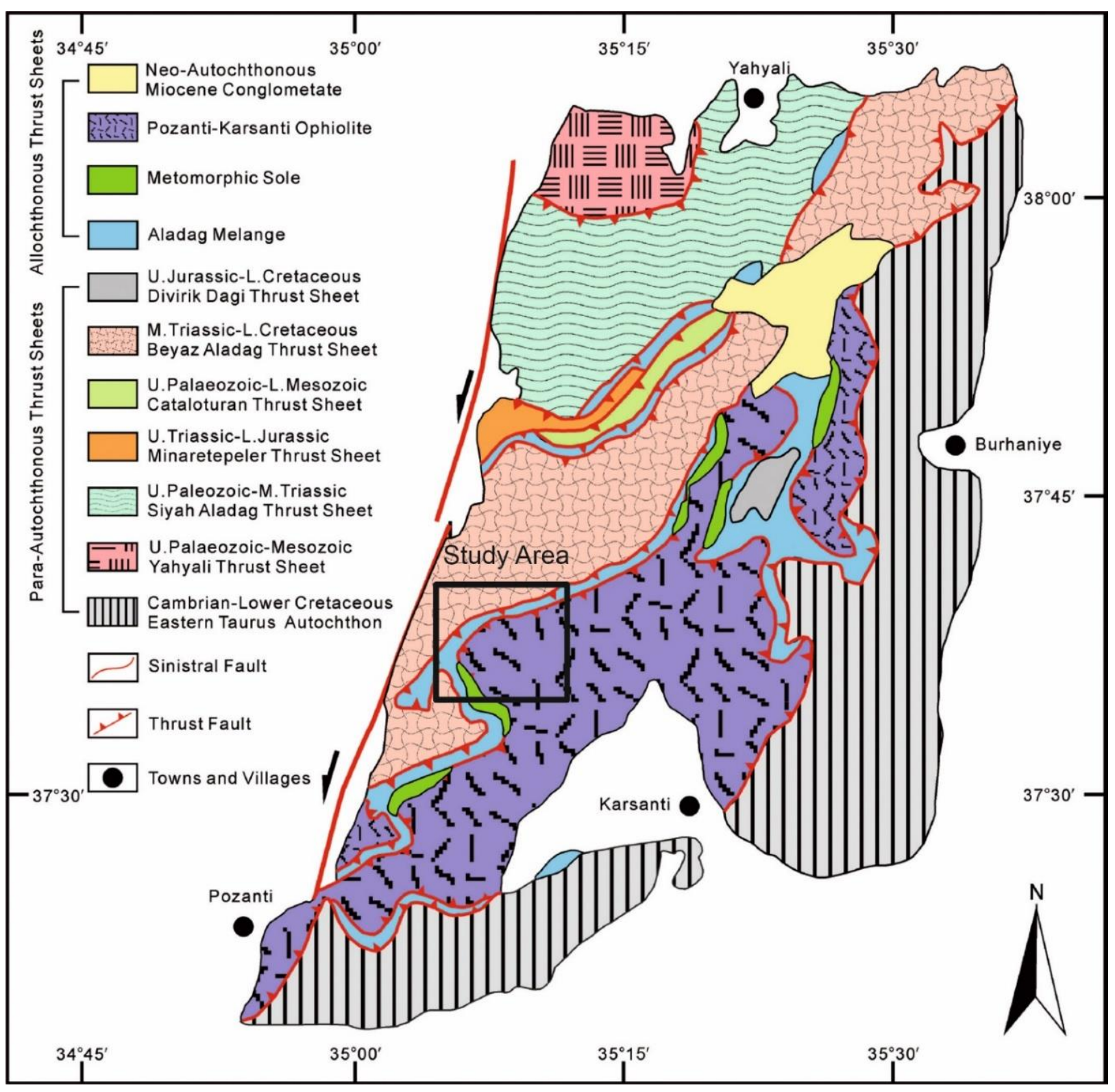

Figure 2. Geological map of the study area and its surroundings (from Bingöl, 1978).

\section{RESULTS}

\subsection{Chromitite Ore Types}

The chromitite ore bodies of Mazmılı field at Pozant1-Karsantı Ophiolite belong to concordant and subconcordant form and are located within mantle harzburgite surrounded by bodies of dunite. Chromitite ore types are small or medium bodies of massive, disseminated, banded and nodular, also the result of a combination of at least two of these types of ores consist of mixed-type ore.

Massive ore bodies consisting of more than 90 vol. \% Cr-spinel are lens, pipe or tabular shapes of highly variable size, lens bodies dominate. The size of individual massive ore bodies ranges from $2-3 \mathrm{~cm}$ to $14-15$ $\mathrm{m}$ thickness and 5-6 $\mathrm{cm}$ up to 60-70 $\mathrm{m}$ in length. The boundaries of the ore bodies with enclosing dunite are either well defined or gradual to disseminated (Figure 3a-d). Plastic deformation signature has been detected in 4-5 cm long massive type ore. Forces acting along the long axis direction of massive ore were effective on the area of incoming force direction (Figure 3a). However, the forces acting along the short axis of other massive ore were also effective on the symmetry of incoming force side at one body (Figure $3 \mathrm{~b}$ ). In the massive ore, this detail was observed as macro (Figure 3d). 


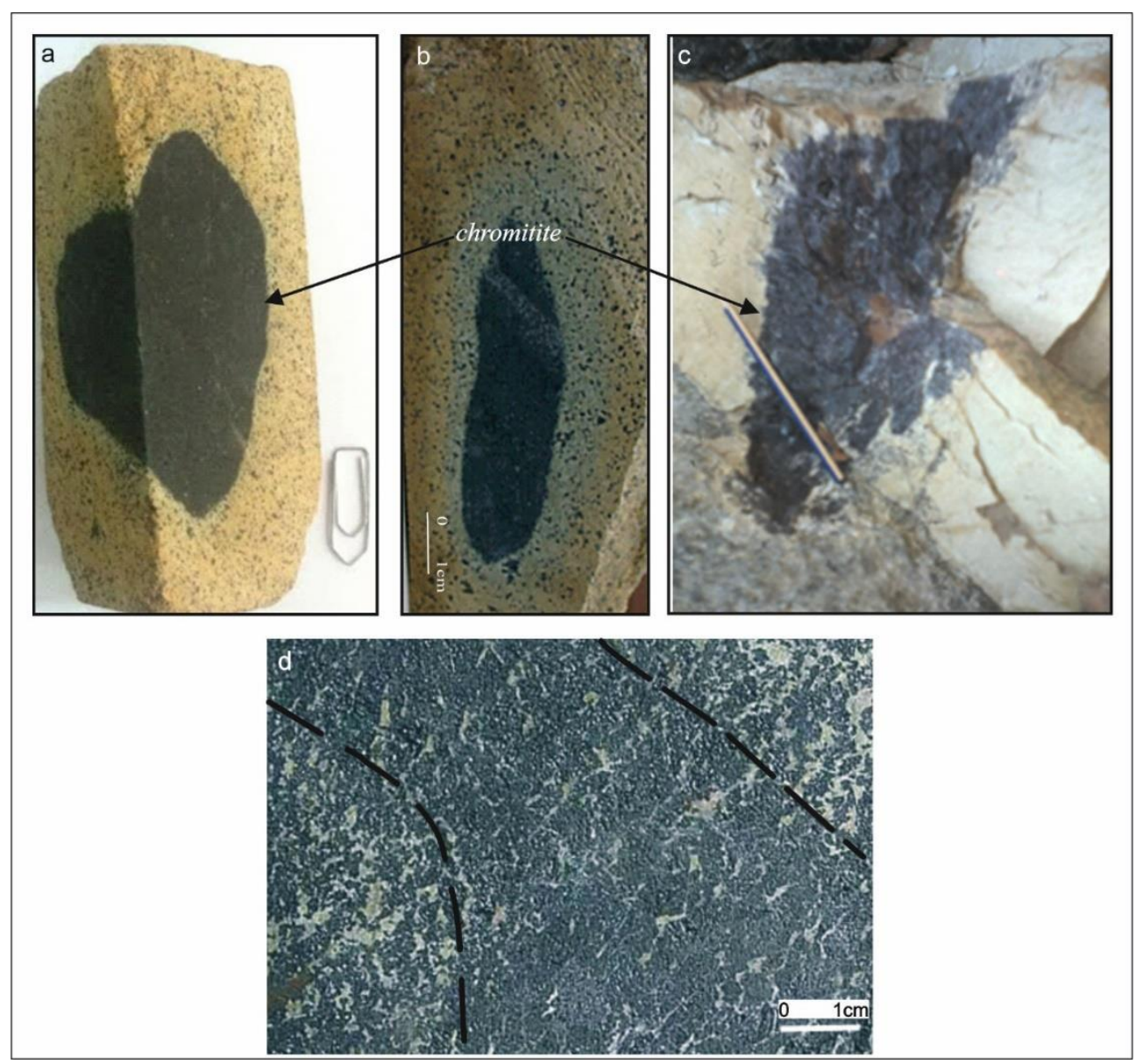

Figure 3. Small-Scaled Massive Ore Samples, a) Sample Showing Deformation in One Direction, b) Deformation on Both Sides of the Massive Sample, c) Small-Scaled Massive ore Containing No Disseminated Ore d) Differences in Massive ore as a Result of Plastic Deformation

Banded ore is located in the very limited areas. Chromitite ore composed of dunite-chromitite alternation. Both dunite and chromitite bands are not sterile and have gradual transitions. The thickness of the bands varies between a few $\mathrm{mm}$ and $\mathrm{cm}$. There are $2-3 \mathrm{~cm}$ long pods and $1-2 \mathrm{~mm}$ thick dunite dikes in chromitite bands. Orientation of the pods are parallel to the bands. (Figure 4). Cr spinel crystals are also found in dunite pods and dykes.

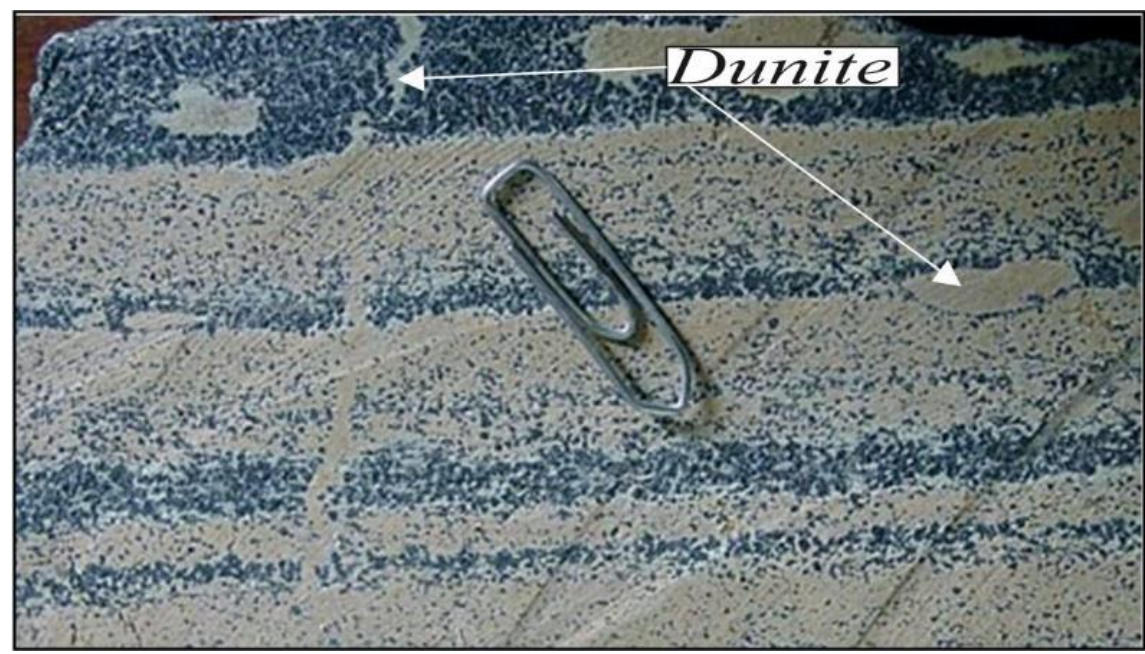

Figure 4. Dunite Pods and Dyke in Banded Chromitite Ore

(Dunite Lenses are Parallel to Chromite Bands and Contain Cr spinels.

Dunite Dykes are Perpendicular to the Banded Chromitite and Contain Cr Spinels.) 
Nodules of chromitite range from 10 to $30 \mathrm{~mm}$ in size and are approximately spherical, ovoid or cubic like. Nodules of different structures can coexist. The nodules are arranged parallel or oblique to the igneous layering. Irregular chromitite bodies are observed between some nodules and their size are smaller than $1 \mathrm{~cm}$. Nodules by the internal structure can be grouped by massive and skeletal olivine. Massive ones consist of 90-95 \% and skeletal olivine ones consist of 85-90 \% chromian spinel. Some nodules can be scattered with showing no contact to each other. Others can be found in the form of chain and get flatted (Figure 5a-f).
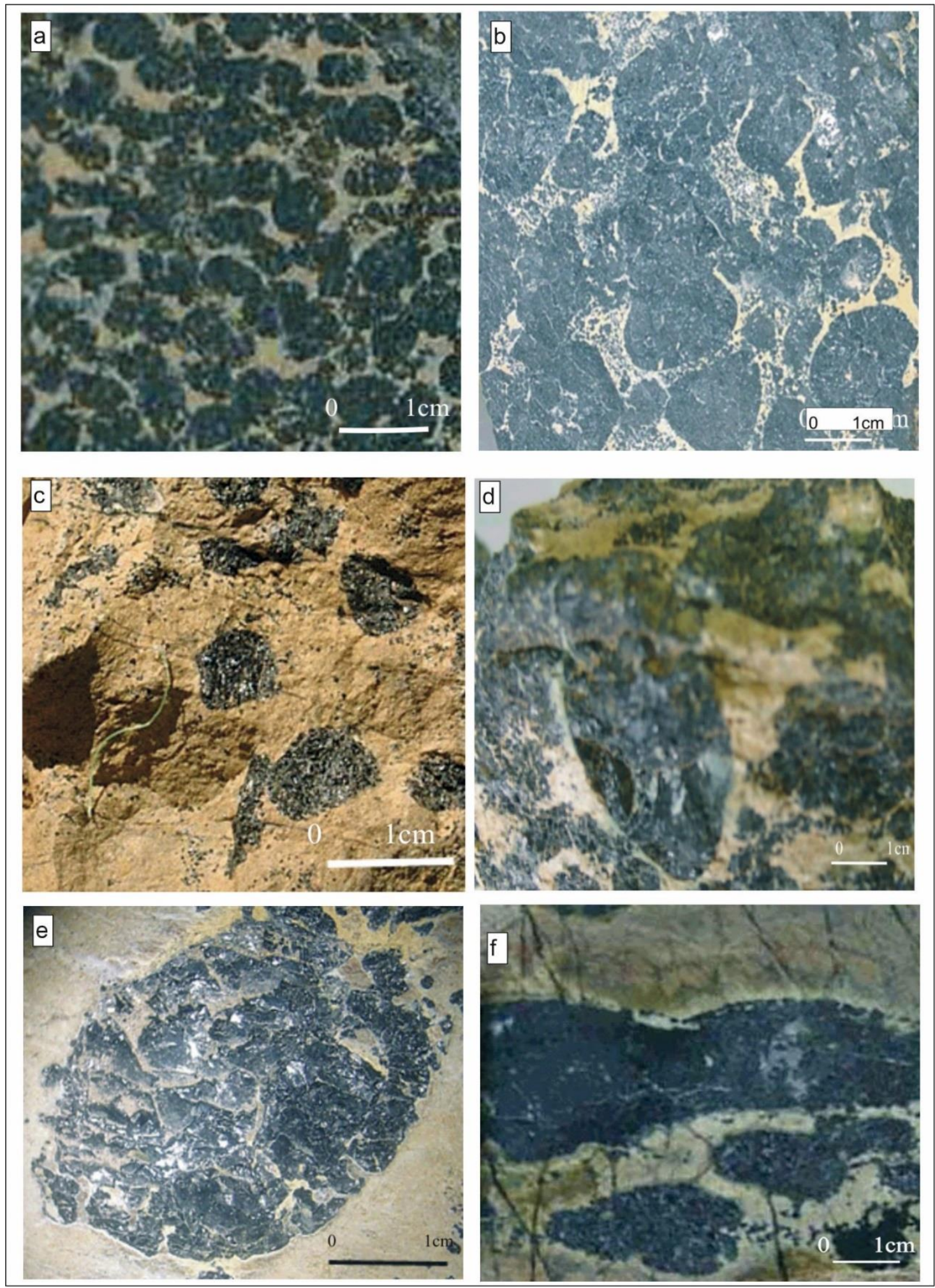

Figure 5. Nodular Chromitite, a), b) Different Size Nodular Chromitite, c), d) Irregular Nodules, e) Skeletal Olivine Nodule Chromite, f) Chain and Get Flatted Nodules 
Disseminated chromitite are found with massive, nodular and banded type ores but also in the form of separate layers. $\mathrm{Cr}$ spinels founded disseminated in the olivines observed as one crystal or groups with 2-3 crystals. There is no orientation in chromite crystals and groups. The sizes of the crystals are quite different, ranging from 0.1 to $0.4 \mathrm{~mm}$. (Figure 6a-b).

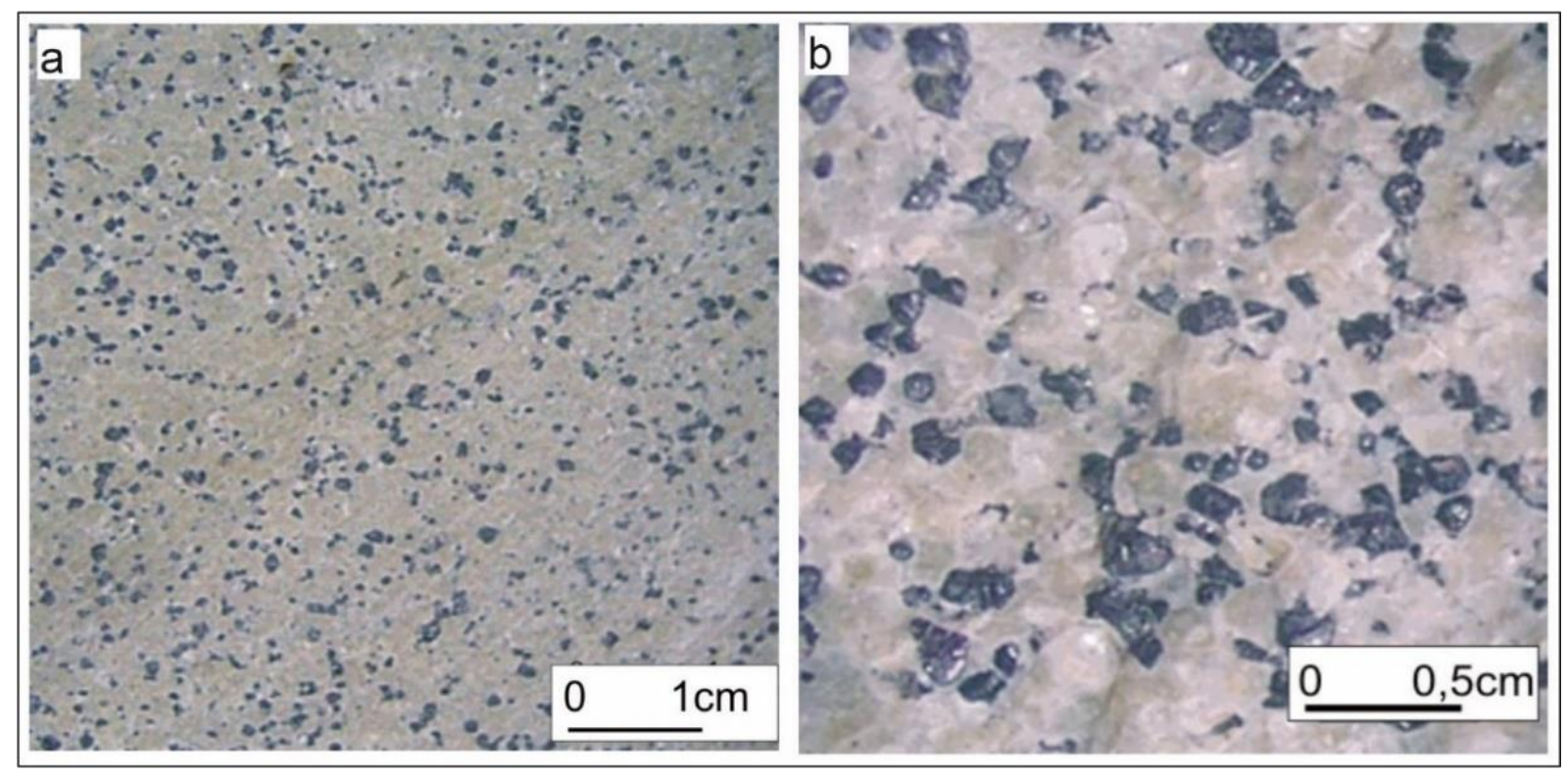

Figure 6. a), b) Disseminated Chromitite Ore Sample

\subsection{Petrography}

Chromitite in Mazmılı (PKO) area hosted in mantle peridotites section are harzburgite and dunite. Both harzburgites and dunites, which host the chromitite mineralization and deposits, were serpantinized, and they showed mesh texture. Harzburgites samples consist of partly serpentinized olivine (65-80\%), orthopyroxene (15-30\%), clinopyroxenes (3-5\%), Cr-spinels (1-2\%) and accessory base metal sulphides.

Based on outcrop of dunite classified as thin envelopes around chromitite pods separating harzburgite and massive body. Mineralogy and textural observation are no disparity between these dunites. According to the descending order of quantity, dunite samples mainly composed serpentinized olivine $(\geq 90 \%)$, ortopyroxene $(<5 \%)$, clinopyroxene $(<1-2 \%)$, Cr-spinels $(<3-4 \%)$ and as accessory base metal sulphides. The serpentine minerals filled the fractures and spaces between crystals of $\mathrm{Cr}$-spinel, relict olivine, pyroxene and accessory base metal sulphides (Figure 7a, b). Cr-spinel in the harzburgite and dunite are structure euhedral, subhedral to anhedral amygdaloidal are form host rocks. Cr-spinels within serpentinized dunite turned into magnetite rims along fractures and was characterized by dark red color (Figure 7c, d). Some $\mathrm{Cr}$ spinels in peridotites have a distinct orientation. (Figure 7e, f).

The Cr-spinel of chromitite are subhedral to euhedral in shape and vary in size from 0.01 to $0,5 \mathrm{~mm}(0.2-0,3$ $\mathrm{mm}$ in average). Cr-spinel crystals showed high reflectivity, and dark to pale gray colors were typical in polished sections. The interstitial matrix of the chromitites consists of olivine, serpentine minerals and accessory base metal sulphide minerals (pentlandite, heazlewoodite and millerite). Most of Cr-spinel had characteristics of pull-apart break texture and micro faults by tectonics. However, samples from imbricate zones exhibited mylonitic and cataclastic textures (Figure 8a, b). Inclusions widely located in Cr-spinels as globular droplets were independent of each other. In certain instances, these droplets showed linear orientation (Figure 8c, d). Silicate inclusions, mainly olivine are interpreted as magmatic minerals based on their textural features by reflecting light microscopy. Base metal sulphide minerals, pentlandite, heazlewoodite and millerite occurred as inclusions in $\mathrm{Cr}$-spinels and serpentine matrix. These inclusions were generally occurred only in trace amounts commonly as single isolated grains. Millerite was the most common base metal sulphides inclusion, according to the reflecting light microscopy studies, (Figure 9a, b). 


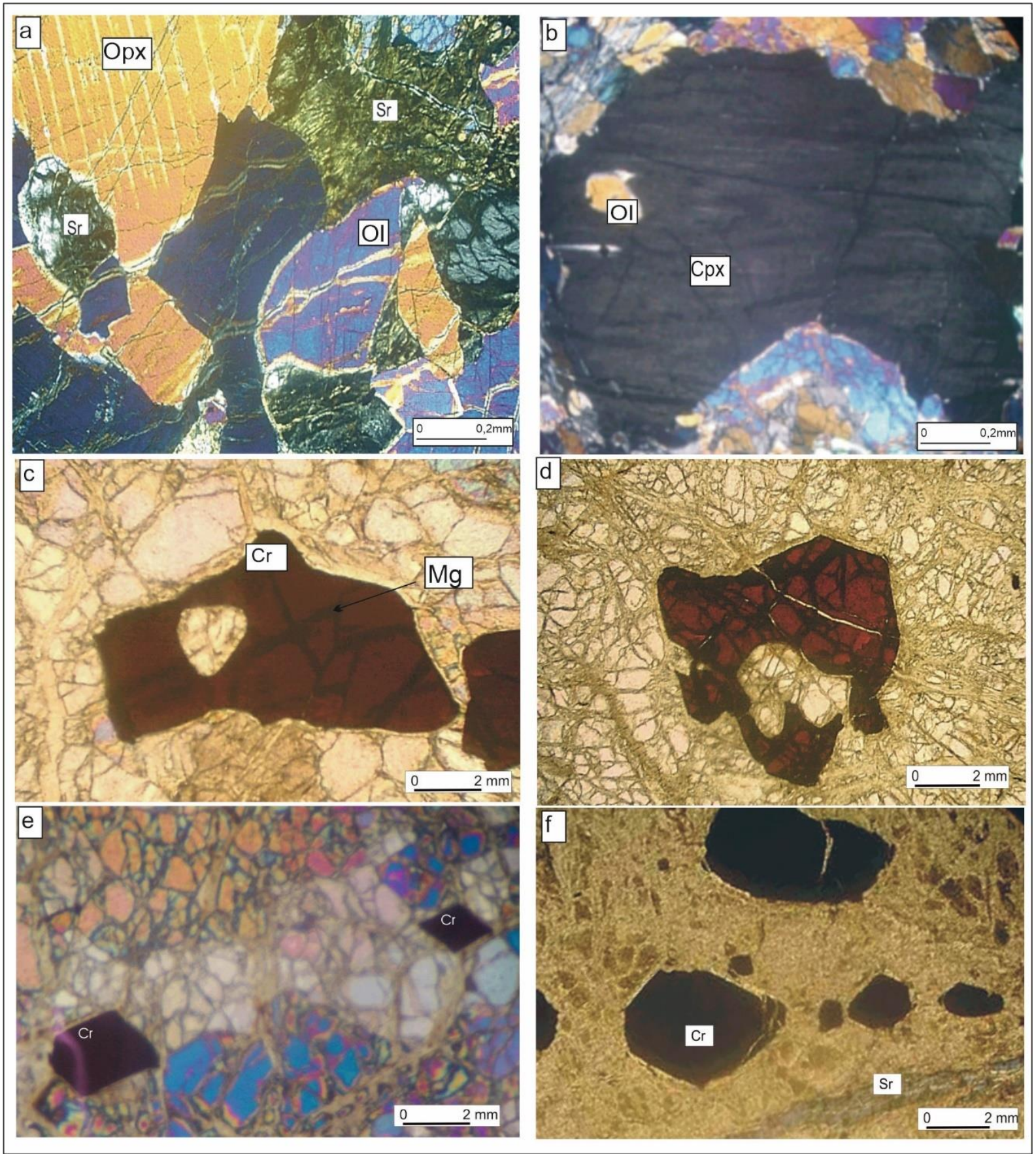

Figure 7. Microphotos of Peridotite Thin Section, a), b) Peridotite Mesh Texture, c), d) Magnetite Rims of Magnetite in Amygdaloidal Cr Spinels in Peridotite,

e) Euhedral Cr Spinesls in Olivine, f) Orientation of Cr Spinels

(Opx: Ortopyroxene, Sr: Sepantine, Ol: Olivine, Cr: Cr Spinel, Mg: Magnetite).

\subsection{Geochemistry}

\subsubsection{Whole-Rock Analysis}

Major oxides and trace element compositions of the semi-quantitative analysed by XR-F methods within oceanic mantle peridotite chromitites, massive, banded, nodular and disseminated are listed in Table 1. Major oxide concentrations are $\mathrm{SiO}_{2}(3,81-46,91 \mathrm{wt} \%), \mathrm{Cr}_{2} \mathrm{O}_{3}$ (7,05-50,84 wt\%), $\mathrm{MgO}$ (15,10-40,09 wt\%), $\mathrm{Al}_{2} \mathrm{O}_{3}(1,18-12,08 \mathrm{wt} \%)$ and $\mathrm{FeO}(\mathrm{t})(6,73-17,37 \mathrm{wt} \%)$. Trace elements concentrations are Ni (1140-2840 ppm), Ti (150-1740 ppm), Co (80-280 ppm), V (90-990 ppm), Zn (50-270 ppm), S (60-160 ppm) and Ca 
(90-10790 ppm). However, $\mathrm{Ga}$ and $\mathrm{Cl}$ elements were not detected above the limit value in all analyses. Therefore, these samples were not taken excluded from the statistical evaluation.
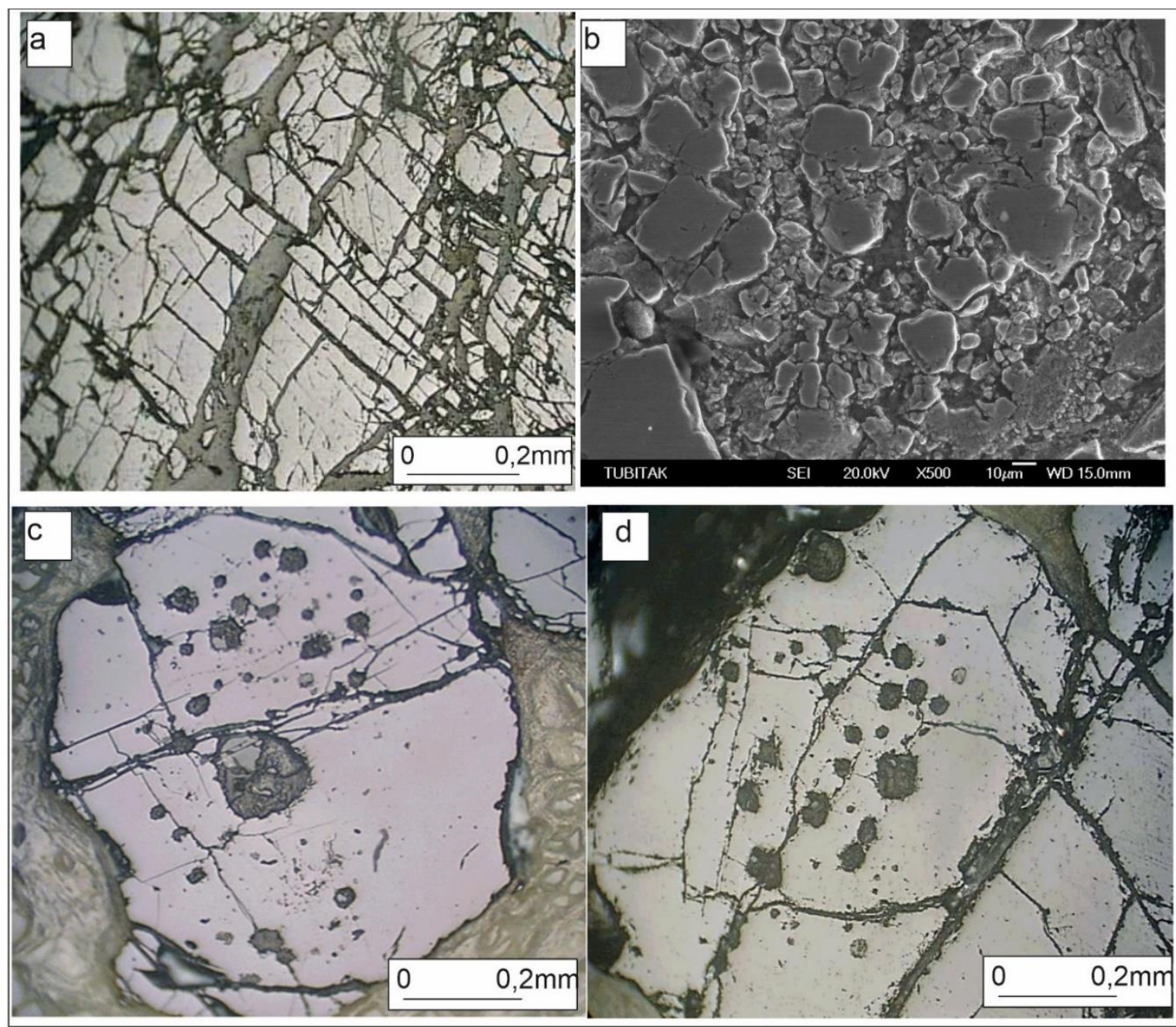

Figure 8. a) Micro Faults and Pull-Apart Break Texture of Cr-Spinel, b) Scanning Electron Microscope Images of Samples from Imbricate Zones within Chromitites, $\boldsymbol{c}), \boldsymbol{d})$ Silicate Inclusions in Cr-Spinel as Droplets (a, $\boldsymbol{c}, \boldsymbol{d}$ : Reflecting Light Microscopy, $\boldsymbol{b}:$ SEM)

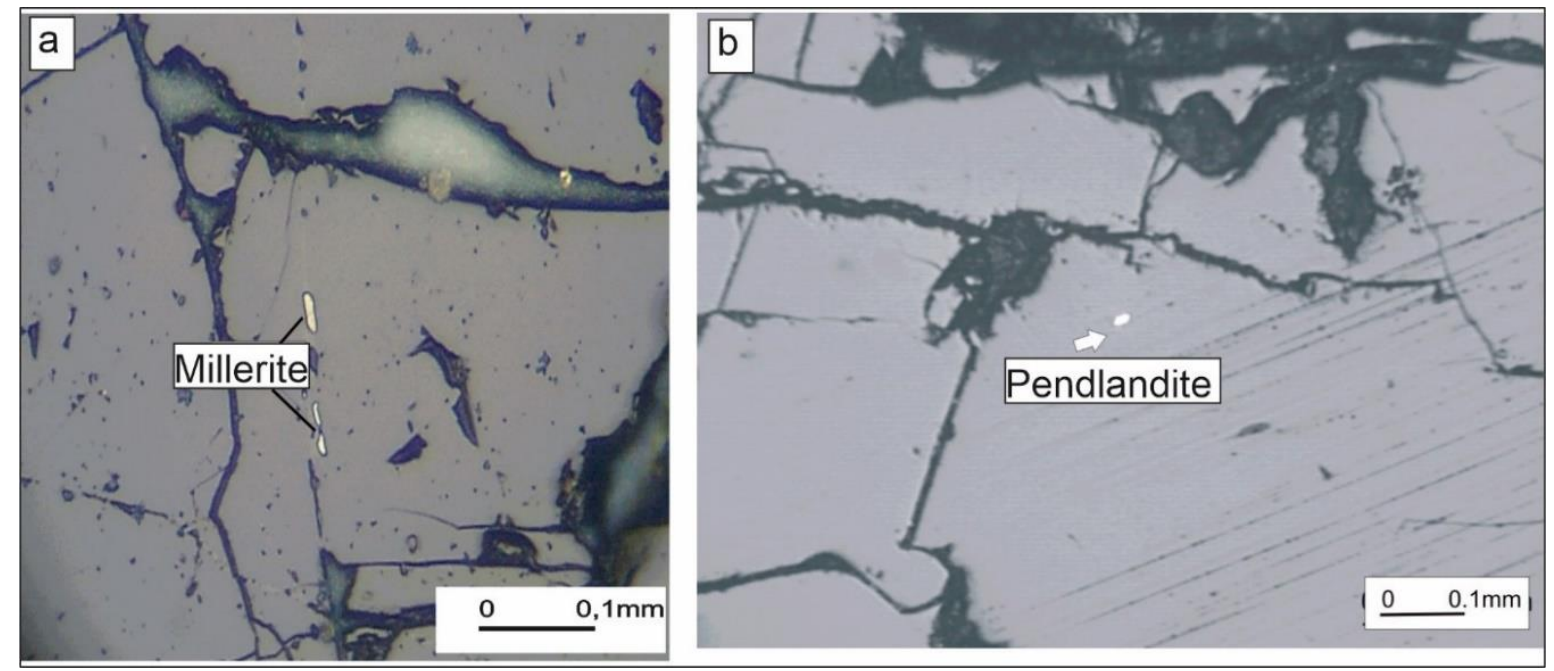

Figure 9. Millerite and Pentlandite in Cr Spinels 
Olivine and $\mathrm{Cr}$ spinel are major components minerals of podiform chromitites. $\mathrm{Cr}$ spinel is an oxide with a spinel-type structure that might be expressed using the general formula $\mathrm{AB}_{2} \mathrm{O}_{4}$. The A site is occupied by $\mathrm{Mg}^{2+}$ and $\mathrm{Fe}^{2+}$ in tetrahedral coordination and the $\mathrm{B}$ site is usually occupied by $\mathrm{Cr}$ and $\mathrm{Al}$ in octahedral coordination; $\mathrm{Cr}$ and $\mathrm{Al}$ may be substituted by $\mathrm{Fe} 3+$ giving rise to ferrian chromite. Elements like $\mathrm{Zn}^{2+}, \mathrm{Co}^{2+}$, $\mathrm{Mn}^{2+}$ and $\mathrm{Ni}^{2+}$ can substitute $\mathrm{Mg}^{2+}$ and $\mathrm{Fe}^{2+}$ in $\mathrm{A}$ and $\mathrm{V}^{3+}, \mathrm{Ga}^{3+}$ and $\mathrm{Ti}^{4+}$ can substitute $\mathrm{Al}$ and $\mathrm{Cr}$ in $\mathrm{B}$. Type of nesosilicate or orthosilicate, Olivine is silicate with the general formula $\mathrm{A}_{2} \mathrm{SiO}_{4}$. The A site is occupied by

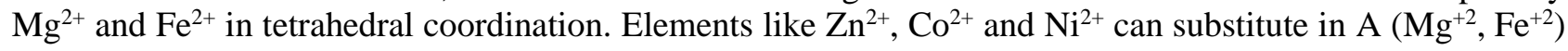
(Table 2) (Colas et al., 2014).

Sulphur is major components inclusion minerals of millerite $(\mathrm{NiS})$, heazlewoodite $\left(\mathrm{Ni}_{3} \mathrm{~S}_{2}\right)$ and pentlandite $\left.(\mathrm{Fe}, \mathrm{Ni})_{9} \mathrm{~S}_{8}\right)$ in $\mathrm{Cr}$ spinel and olivine. The low $\mathrm{Ca}$ contents are conformable with clinopyroxene abundance. Despite the different degree of serpentinization, the samples, major oxide and trace element concentrations do not appear to have been greatly modified and the major oxide and trace element contents are compatible with the mineralogical-petrological observations.

Table 1. The Major Oxide and Trace Element Values of the Ore Samples Belonging to the Study Area (-: below detection limits, $t$ : total)

\begin{tabular}{|c|c|c|c|c|c|c|c|c|c|c|}
\hline \multicolumn{11}{|c|}{ Major Oxides (wt \%) } \\
\hline & 1 & 2 & 3 & 4 & 5 & 6 & 7 & 8 & 9 & 10 \\
\hline $\mathrm{SiO}_{2}$ & 46,91 & 42,33 & 12,45 & 3,81 & 34,70 & 31,64 & 23,87 & 38,75 & 30,61 & 41,58 \\
\hline $\mathrm{Cr}_{2} \mathrm{O}_{3}$ & 11,26 & 14,24 & 40,88 & 50,84 & 16,67 & 26,53 & 34,91 & 14,96 & 20,80 & 7,05 \\
\hline $\mathrm{MgO}$ & 33,57 & 33,85 & 23,36 & 15,10 & 37,03 & 28,99 & 25,40 & 35,22 & 35,11 & 40,09 \\
\hline $\mathrm{Al}_{2} \mathrm{O}_{3}$ & 1,18 & 1,77 & 11,44 & 12,08 & 3,27 & 4,25 & 5,46 & 1,93 & 4,61 & 1,81 \\
\hline $\mathrm{FeO}_{(\mathrm{t})}$ & 6,73 & 7,18 & 11,34 & 17,37 & 7,56 & 8,10 & 9,79 & 7,01 & 8,19 & 8,65 \\
\hline Total & 98,65 & 99,37 & 99,47 & 99,28 & 99,23 & 99,51 & 99,43 & 99,87 & 99,32 & 99,18 \\
\hline \multicolumn{11}{|c|}{ Trace elements (ppm) } \\
\hline $\mathrm{Ni}$ & 2840 & 2590 & 1710 & 1140 & 2630 & 1740 & 1890 & 2810 & 2380 & 2780 \\
\hline $\mathrm{Ti}$ & 220 & 300 & 520 & 1740 & 370 & 560 & 600 & 300 & 540 & 150 \\
\hline$S$ & 100 & 150 & 80 & 60 & 110 & 90 & 60 & 160 & 120 & 130 \\
\hline $\mathrm{Ca}$ & 5880 & 280 & 90 & 110 & 1540 & 190 & 180 & 10790 & 390 & 840 \\
\hline Co & 80 & 110 & 200 & 280 & 110 & 110 & 130 & 90 & 110 & 130 \\
\hline $\mathrm{V}$ & 120 & 170 & 700 & 990 & 210 & 290 & 400 & 190 & 290 & 90 \\
\hline $\mathrm{Zn}$ & 50 & 70 & 200 & 270 & 80 & 110 & 160 & 60 & 110 & 60 \\
\hline $\mathrm{Ga}$ & - & 850 & 20 & 20 & - & - & - & - & - & - \\
\hline $\mathrm{Cl}$ & 490 & - & - & 230 & 760 & 230 & 50 & 980 & 870 & 840 \\
\hline
\end{tabular}


Table 2. Major, minor and trace element in Cr spinel and olivine mineral structures (Modified from ied from Colás et al., 2014; Huang \& Deng, 2020).

\begin{tabular}{|c|c|c|c|c|c|c|c|}
\hline Mineral & IMA Classification & Formula & Position & $\mathrm{Ma}$ & jor element & Trac & element \\
\hline \multirow{7}{*}{ Chromite } & \multirow{7}{*}{ Spinel subgroup } & \multirow{7}{*}{$\mathrm{AB}_{2} \mathrm{O}_{4}$} & \multirow{4}{*}{$\mathrm{A}^{(\mathrm{IV})}$} & Element & Ionic Radius $(\AA)$ & Element & $\begin{array}{c}\text { Ionic } \\
\text { Radius }(\AA)\end{array}$ \\
\hline & & & & \multirow{2}{*}{$\mathrm{Mg}^{+2}$} & \multirow{2}{*}{0,57} & $\mathrm{Zn}^{+2}$ & 0,6 \\
\hline & & & & & & $\mathrm{Co}^{+2}$ & 0,58 \\
\hline & & & & $\mathrm{Fe}^{+2}$ & 0,63 & $\mathrm{Ni}^{+2}$ & 0,55 \\
\hline & & & \multirow{3}{*}{$\mathrm{B}^{(\mathrm{IV})}$} & $\mathrm{Cr}^{+3}$ & 0,615 & $\mathrm{~V}^{+3}$ & 0,64 \\
\hline & & & & $\mathrm{Al}^{+3}$ & 0,535 & $\mathrm{Ga}^{+3}$ & 0,62 \\
\hline & & & & $\mathrm{Fe}^{+3}$ & 0,645 & $\mathrm{Ti}^{+4}$ & 0,60 \\
\hline Olivine & Olivine group & $\mathrm{A}_{2} \mathrm{SiO}_{4}$ & $\mathrm{~A}^{(\mathrm{II})}$ & $\begin{array}{l}\mathrm{Mg}^{+2} \\
\mathrm{Fe}^{+2}\end{array}$ & $\begin{array}{l}0,57 \\
0,63\end{array}$ & $\begin{array}{c}\mathrm{Zn}^{2+}, \\
\mathrm{Co}^{2+} \\
\mathrm{Ni}^{2+}\end{array}$ & $\begin{array}{c}0,6 \\
0,68 \\
0,55 \\
\end{array}$ \\
\hline
\end{tabular}

Whole rock analysis of trace elements in the binary diagram drawn according to the amount of $\mathrm{Cr}_{2} \mathrm{O}_{3}$ and $\mathrm{SiO}_{2}$ showed two different results, due to $\mathrm{Cr}$ and $\mathrm{Si}$ main component elements of $\mathrm{Cr}$ spinel and olivine. The whole rock $\mathrm{Zn}, \mathrm{V}$, Ti and Co contents had positive correlation but $\mathrm{Ni}, \mathrm{S}$ and Ca negative with $\mathrm{Cr}_{2} \mathrm{O}_{3}$. While, $\mathrm{Zn}, \mathrm{V}, \mathrm{Ti}$, and $\mathrm{Co}$ had negative correlation, $\mathrm{Ni}, \mathrm{S}$ and $\mathrm{Ca}$ positive correlation with $\mathrm{SiO}_{2}$ (Figure 10a-n).

The correlation coefficients between the contents of the trace elements and major oxides from Table 1 were calculated to examine the inter-trace element and major oxides relationships in the chromitite (Table 3). Inter trace element and major oxides positive correlation is found between $\mathrm{Cr}_{2} \mathrm{O}_{3}, \mathrm{Al}_{2} \mathrm{O}_{3}, \mathrm{FeO}_{(\mathrm{t})}, \mathrm{Ti}, \mathrm{Co}, \mathrm{V}$ and $\mathrm{Zn}$, $\mathrm{V}$ and $\mathrm{Zn}$, implying a directly proportional relationship between them, furthermore negative correlation between these elements and $\mathrm{MgO}, \mathrm{SiO}_{2}, \mathrm{~S}$ and $\mathrm{Ca}$ (Table 3).

Table 3. Correlation Coefficients (r) for Selected Trace and Major Oxides in Chromitites from PKO Mantle Peridotite

\begin{tabular}{|c|c|c|c|c|c|c|c|c|c|c|c|c|}
\hline & $\mathrm{SiO}_{2}$ & $\mathrm{Cr}_{2} \mathrm{O}_{3}$ & $\mathrm{MgO}$ & $\mathrm{Al}_{2} \mathrm{O}_{3}$ & $\mathrm{FeO}_{(\mathrm{t})}$ & $\mathrm{Ni}$ & $\mathrm{Ti}$ & $S$ & $\mathrm{Ca}$ & Co & $\mathrm{V}$ & $\mathrm{Zn}$ \\
\hline $\mathrm{SiO}_{2}$ & 1 & & & & & & & & & & & \\
\hline $\mathrm{Cr}_{2} \mathrm{O}_{3}$ & $-0,98$ & 1 & & & & & & & & & & \\
\hline $\mathrm{MgO}$ & 0,89 & $-0,95$ & 1 & & & & & & & & & \\
\hline $\mathrm{Al}_{2} \mathrm{O}_{3}$ & $-0,98$ & 0,95 & $-0,85$ & 1 & & & & & & & & \\
\hline $\mathrm{FeO}_{(\mathrm{t})}$ & $-0,91$ & 0,87 & $-0,82$ & 0,89 & 1 & & & & & & & \\
\hline $\mathrm{Ni}$ & 0,92 & $-0,96$ & 0,92 & $-0,89$ & $-0,84$ & 1 & & & & & & \\
\hline $\mathrm{Ti}$ & $-0,85$ & 0,85 & $-0,84$ & 0,79 & 0,93 & $-0,84$ & 1 & & & & & \\
\hline S & 0,79 & $-0,80$ & 0,79 & $-0,71$ & $-0,67$ & 0,80 & $-0,63$ & 1 & & & & \\
\hline $\mathrm{Ca}$ & 0,44 & $-0,42$ & 0,40 & $-0,45$ & $-0,40$ & 0,55 & $-0,33$ & 0,52 & 1 & & & \\
\hline Co & $-0,90$ & 0,85 & $-0,80$ & 0,91 & 0,98 & $-0,82$ & 0,86 & $-0,61$ & $-0,44$ & 1 & & \\
\hline V & $-0,97$ & 0,96 & $-0,90$ & 0,97 & 0,94 & $-0,90$ & 0,89 & $-0,70$ & $-0,37$ & 0,95 & 1 & \\
\hline $\mathrm{Zn}$ & $-0,99$ & 0,98 & $-0,91$ & 0,97 & 0,94 & $-0,94$ & 0,88 & $-0,77$ & $-0,48$ & 0,93 & 0,98 & 1 \\
\hline
\end{tabular}




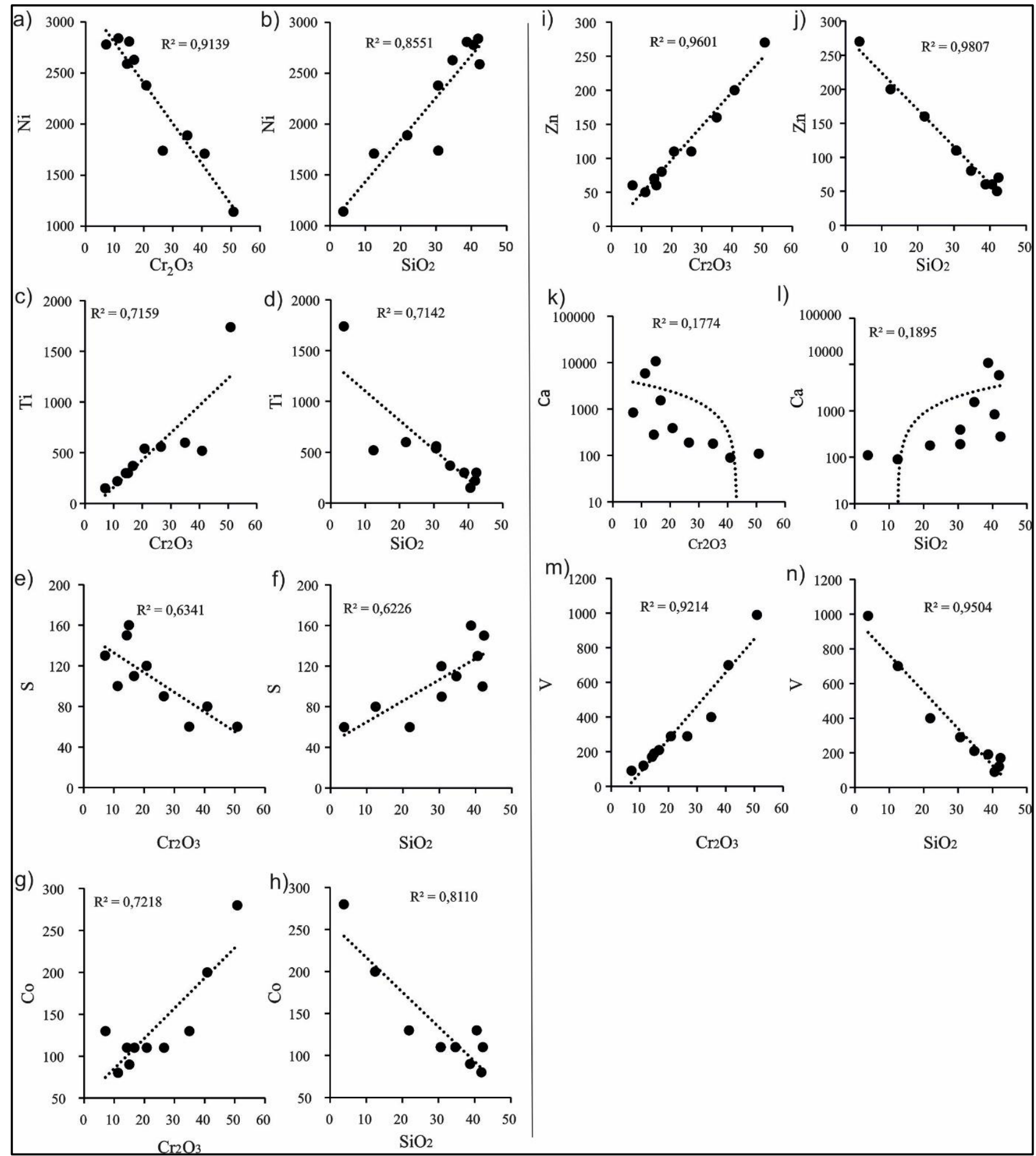

Figure 10. a), n) Whole Rock Binary Diagrams of $\mathrm{Cr}_{2} \mathrm{O}_{3}$ and $\mathrm{SiO}_{2}$ Versus Trace Elements

\section{DISCUSSION}

Podiform Chromite deposits occur as autoliths in the upper mantle tectonites of harzburgite ophiolite types (HOT) (Pearce et al., 1984; Boudier \& Nicolas, 1985; Roberts, 1988) and their sizes and distributions are difficult to predict other than their obvious orientation. (Dickey, 1976). By Cassard et al. (1981). They distinguish between congruent, discordant, and unconformable compartments depending on their attitude to the foliation-lineation reference frame in the surrounding plastically deformed peridotite. It is quite difficult to define the chromite ore types in ophiolites, but in general, disseminated, massive, banded, nodular and network structures are common (Thayer, 1964, 1969; Greenbaum, 1977; Brown, 1980; Leblanc, 1980; Duke, 
1983). Some ore types are unique to ophiolites, these are nodular, orbicular and coarse crystalline ores (Thayer, 1964).

Podiform chromitites in the study area are massive, banded, disseminated and nodular. It was observed that the chromite masses were exposed to plastic deformation. The bodies forming the ore are under the influence of lateral forces and exhibit elastic behavior in the direction of the incoming force. Especially in the massive ore structure, these deformations are clearly observed. The nodular ore in the region has highly varying properties. Most of ore nodules have the ellipsoidal structure, there are also same cubic structures. The internal structure of the nodules is not homogeneous, and there are two different types of structures (skeletal and massive). The skeletal crystals within the nodules are single crystals that are surrounded by a rim of polycrystalline chromite. The nodules impinged on each other causing local deformation at points of contact (Prichard et al., 2015). There are olivine pods and micro dykes within the banded chromites. The long axes of dunite pods are parallel to each other and no crossing pods were encountered. Small-scale $(5-10 \mathrm{~cm})$ massive chromitite ore has plastic deformations applied by lateral forces. Plastic deformation traces are also seen in the nodular ore, in the bands formed by the nodules coming together, and in the aligning of the inclusions in the $\mathrm{Cr}$ spinel crystals in a certain direction. Accordingly, it can be said that chromite ore remained under the influence of lateral forces and showed plastic deformation before it solidified completely.

The lack of geochemical distinction between the different podiform type deposit suggests that they may have had similar origins (Cassard et al., 1981). The variation of minor and trace elements in podiform chromite can be used in petrography and environment interpretation of ores in tectonites (Yu et al., 2020). Limited exchange of elements does not substantially modify the original composition in chromite cores (Colas et al., 2014). Therefore, they help to clarify the trace element values of chromites in mineralogic-petrographic studies (Dare et al., 2009; Colás et al., 2014).

A total of 10 massive, nodular, disseminated and banded ore samples were analyzed chemically by XRF method. According to the results obtained in the main oxide and trace element values in the analyzed samples, their possible distributions in chromite and host rock were determined. While a positive relationship has detected between the trace elements $\mathrm{Ti}, \mathrm{Co}, \mathrm{Zn}$ and $\mathrm{V}$ and $\mathrm{Cr}_{2} \mathrm{O}_{3}$, there have a negative relationship between $\mathrm{Ni}, \mathrm{S}$ and $\mathrm{Ca}$. The detected $\mathrm{Cr}_{2} \mathrm{O}_{3}$ and trace element changes have an opposite relationship with olivine, the main mineral of dunites, which is the host rock of the chromite ore.

Compared to major elements, trace elements in chromites are more sensitive to formation conditions including pressure, temperature, oxygen fugacity and degree of partial melting and fractional crystallization (Dare et al., 2009; González-Jiménez et al., 2014). Especially, some trace elements (e.g., Ti, Ga, and V) can enter the octahedral site of the crystal structure of the chromite and replace the trivalent elements of $\mathrm{Cr}, \mathrm{Al}$, and $\mathrm{Fe}^{3+}$, resulting in general varieties of chromites (Gervilla et al., 2012).

\section{CONCLUSION}

Chromite ore types in the study area are massive, banded, disseminated and nodular in accordance with the podiform chromite deposits. Chromite ores bear traces of plastic deformation under the influence of lateral forces developing in the lateral direction. Plastic deformation is also observed at the micro scale.

According to the chromite ore whole-rock geochemical analysis, there was a positive relationship between the amount of $\mathrm{Cr}_{2} \mathrm{O}_{3}$ and $\mathrm{Zn}, \mathrm{V}, \mathrm{Ti}$, and $\mathrm{Co}$, while a negative relationship was found between $\mathrm{Ni}$, $\mathrm{S}$ and $\mathrm{Ca}$. This situation is opposite with the dunites in which the chromite ore is located.

\section{ACKNOWLEDGMENTS}

This study was supported by FBE. 2001/021 of N. Omer Halisdemir University.

\section{CONFLICT OF INTEREST}

The authors declare no conflict of interest. 


\section{REFERENCES}

Anıl, M. (1990). Pozant1-Karsantı, Mersin ve Kızıldağ (Hatay) Ofiyolitlerindeki Bazı Kromit Yataklarının Morfolojik Yapısal ve Jenetik Özellikleri ile Akdeniz Bölgesindeki Benzer Kromit Yataklarının Karşılaştırılması. Doğa, 14, 645-675, Ankara.

Blumenthal, M. (1946), Kilikya Toros'larının Çok Dikkate Değer Bir Parçası: Karanfildağ. MTA Mecmuası, 2. 257-286.

Boudier, F., \& Nicolas, A. (1985) Harzburgite and lherzolite subtypes in ophiolitic and oceanic environments. Earth and Planet. Science Letters, 76(1-2), 84-92. doi:10.1016/0012-821X(85)90150-5

Brown, M. (1980). Textural and geochemical evidence for the origin of some chromite deposits in the Oman ophiolite. In: A. Panayiotou (Eds.) Ophiolites, Proceed. Intern. Ophiolite Symp. Cyprus, 714-721. Geol. Surv. Dep., Nicosia.

Cassard, D., Nicolas, A., Rabinovitch, M., Moutte, J., Leblanc, M., \& Prinzhofer, A., (1981). Structural classification of chromite pods in southern New Caledonia. Economic Geology, 76(4), 805- 831. doi:10.2113/gsecongeo.76.4.805

Choi, S. H., Shervais, J. W., \& Mukasa, S. B. (2008). Supra-subduction and abyssal mantle peridotites of the Coast range ophiolite, California. Contributions to Mineralogy and Petrology, 156, 551-576. doi:10.1007/s00410-008-0300-6

Colás, V., González-Jiménez, J. M., Griffin, W. L., Fanlo, I., Gervilla, F., O’Reilly, S. Y., Pearson, N. J., Kerestedjian, T., \& Proenza, J. A. (2014). Fingerprints of Metamorphism in Chromite: New Insights from Minor and Trace Elements. Chemical Geology, 389, 137-152. doi:10.1016/j.chemgeo.2014.10.001

Çakır, Ü. (1978). Petrologie Du Masisf De Pozant1-Karsant1 (Taurus Cilicien, Turquie): Etude La Partie Centralla. These De Doctorat d'Ing. Univ. Satrasbourg. p. 251. (unpublished).

Dare, S. A. S., Pearce, J. A., McDonald, I., \& Styles, M. T. (2009). Tectonic Discriminationof Peridotites Using fO2-Cr\# and Ga-Ti-FeIII Systematics in Chrome-Spinel. Chemical Geology, 261(3-4), 199-216. doi:10.1016/j.chemgeo.2008.08.002

Dickey, J. S. (1976). A Hypothesis of Origin For Podiform Chromite Deposits. Chromium: its Physicochemical Behavior and Petrologic Significance, 1061-1074. doi:10.1016/B978-0-08-0199542.50026-3

Dilek, Y., \& Robinson, P. T. (Eds.) (2003). Ophiolites in Earth History. Geological Society, London, Special Publications, 218. doi:10.1029/2004EO440009

Dilek, Y., \& Morishita, T. (2009). Melt migration and upper mantle evolution during incipient arc construction: Jurassic Eastern Mirdita ophiolite, Albania. Island Arc, 18(4), 551-554. doi:10.1111/j.14401738.2009.00692.x

Duke, J. M., (1983). Ore Deposit Models 7. Magmatic Segregation Deposits of Chromite. Geoscience Canada, 10(1), 15-24.

Gervilla, F., Padro'n-Navarta, J. A., Kerestedjian, T., Sergeeva, I., González-Jiménez, J. M., \& Fanlo, I. (2012). Formation of ferrian chromite in podiform chromitites from the Golyamo Kamenyane serpentinite, Eastern Rhodopes, SE Bulgaria: a two stage process. Contributions to Mineralogy and Petrology, 164, 643657. doi: $10.1007 / \mathrm{s} 00410-012-0763-3$

Greenbaum. D. (1977). The chromitiferous rocks of the Troodos ophiolite complex, Cyprus. Economic Geology, 72(7): 1175-1194. doi:10.2113/gsecongeo.72.7.1175

Huang, Y., \& Deng, H. (2020) Geochemical Characteristics of Zoned Chromites in Peridotites from the Proterozoic Miaowan Ophiolitic Complex, Yangtze Craton: Implications for Element Mobility and Tectonic Setting. Journal of Earth Science, 31(2), 223-236. doi:10.1007/s12583-019-1278-X

Leblanc, M. (1980). Chromite growth, dissolution and deformation from a morphological view point: SEM investigations. Mineralium Deposita, 15(2), 201-210. doi:10.1007/BF00206514 
Lian, D., Yang, J., Dilek, Y., Wu, W., Zhang, Z., Xiong, F., Liu, F., \& Zhou. W. (2017). Deep mantle origin and ultra-reducing conditions in podiform chromitite: Diamond, moissanite, and other unusual minerals in podiform chromitites from the Pozanti-Karsanti ophiolite, southern Turkey. American Mineralogist, 102(5), 1101-1113. doi: $10.2138 / \mathrm{am}-2017-5850$

Niu, Y., Langmuir, C. H., \& Kinzler, R. J. (1997). The origin of abyssal peridotites: a new perspective. Earth and Planetary Science Letters 152, 251-265. doi:10.1016/S0012-821X(97)00119-2

Parlak, O., Höck, V., \& Delaloye. M. (2002). The Supra-Subduction Zone Pozant1-Karsant1-Ophiolite Southern Turkey: Evidence For High-Pressure Crystal Fractionation of Ultramafic Cumulates. Lithos, 65(12), 205-224. doi:10.1016/s0024-4937(02)00166-4

Pearce, J. A., Lippard, S. J., \& Roberts, S. (1984). Characteristics and tectonic significance of suprasubduction zone ophiolites. Geological Society, London, Special Publications, 16, 77-94. doi:10.1144/GSL.SP.1984.016.01.06

Polat, A., \& Casey, J. F. (1995). A Stuructural Record of The Emplacement of the Pozant1-Karsant1 Ophiolite onto the Menderes-Taurus Block in The Late Cretaceus, Eastren Taurides, Turkey. Journal of Structural Geology, 17(12), 1673-1688. doi:10.1016/0191-8141(95)00061-h

Prichard, H. M., Barnes, S. J., Godel, B., Reddy, S. M., Vukmanovic, Z., Halfpenny, A., Neary, C. R., \& Fisher, P. C. (2015). The structure of and origin of nodular chromite from the Troodos ophiolite, Cyprus, revealed using high-resolution X-ray computed tomography and electron backscatter diffraction. Lithos, 218219, 87-98. doi:10.1016/j.lithos.2015.01.013

Roberts, S. (1988). Ophiolitic chromitite formation: a marginal basin phenomenon. Economic Geology, 83(5), 1034-1036. doi:10.2113/gsecongeo.83.5.1034

Takazawa, E., Frey, F. A., Shimizu, N., \& Obata, M. (2000). Whole rock compositional variations in an upper mantle peridotite (Horoman, Hokkaido, Japan): are they consistent with a partial melting process? Geochemica et Cosmochimica Acta, 64(4), 695-716. doi:10.1016/S0016-7037(99)00346-4

Tekeli, O. (1981). Toros'larda Aladağ Ofiyolitli Melanjının Özellikleri. Türkiye Jeoloji Bülteni, 24, 57-64.

Tekeli, O., Aksay, A., Ürgün, B. M. \& Işı1k, A. (1984). Geology of the Aladağ Mountains. Geology Of The Taurus Belt: Procedings Int. Sym., 26-29. September., 143-149. Ankara. Turkey.

Thayer, T. P. (1964). Principal Features and origin of podiform chromite deposits and some observations on the Guleman-Soridag District, Turkey. Economic Geology, 59(8), 1497-1524. doi:10.2113/gsecongeo.59.8.1497

Thayer, T. P. (1969). Peridodite-gabbro complexes as keys to petrology of mid-ocean ridges. Geological Society of American Bulletin, 80(8), 1511-1522. doi:10.1130/0016-7606(1969)80[1515:PCAKTP]2.0.CO;2

Uysal, I., Ersoy, E. Y., Karsli, O., Dilek, Y., Sadiklar, M. B., Ottley, C. J., Tiepolo, M., \& Meisel, T. (2012). Coexistence of abyssal and ultra-depleted SSZ type mantle peridotites in a Neo-Tethyan Ophiolite in SW Turkey: Constraints from mineral composition, whole-rock geochemistry (major-trace-REE-PGE), and ReOs isotope systematics. Lithos, 132-133, 50-69. doi:10.1016/j.lithos.2011.11.009

Yetiş, C. (1978). Geology of the Çamardı (Niğde) Region and the Characterics of the Ecemiş Fault Zone Between Maden Bogazı and Kamışl1. İstanbul Ünv. Fen Fak. Mecm. Seri E. 43, 41-61. (unpublished).

Yu, H., Zhang, H-F., Zou, H-B. \& Yang, Y-H. (2019). Minor and trace element variations in chromite from the Songshugou dunites, North Qinling Orogen: Evidence for amphibolite-facies metamorphism. Lithos, 328-329, 146-158. doi:10.1016/j.lithos.2019.01.009 